\title{
The influence of parenting parents on the personal hygiene independence of students with disabilities
}

\author{
Tya Juliana ${ }^{1}$, Muya Barida ${ }^{1^{*}}$ \\ ${ }^{1}$ Universitas Ahmad Dahlan, Yogyakarta, Indonesia \\ ${ }^{*}$ Corresponding author, ఏe-mail: muya.barida@bk.uad.ac.id
}

\begin{abstract}
Independence of children's personal hygiene is influenced by parenting parents. This study aims to determine the effect of parenting parents on the personal hygiene independence of children with special needs in SLB / G-AB Helen Keller Indonesia. This type of research is quantitative with descriptive correlational research design. Respondents in this study were parents and students. The sampling technique uses saturated samples. Data analysis uses regression analysis. Based on the results of the study note that for $0.004(0.004<0.05)$ the value of the influence of authoritarian parenting, the value of the influence of democratic parenting is $0.029(0.029<0.05)$ and $0.032(0.032<0.05)$ the value of permissive parenting. Based on the explanation above, it can be concluded that the type that most influences children's personal hygiene independence is authoritarian parenting has the most significant and positive influence on the personal hygiene independence of children with special needs in SLB / G-AB Helen Keller Indonesia.
\end{abstract}

Keywords: Parenting parent, personal hygiene, students with disabilities, children with special need, segregative school

How to Cite: Barida, M. (2020). The influence of parenting parents on the personal hygiene independence of students with disabilities. COUNS-EDU: The International Journal of Counseling and Education, 5(3). 107-114. DOI: http://dx.doi.org/10.23916/0020200526030

This is an open access article distributed under the Creative Commons Attribution License, which permits unrestricted use, distribution, and reproduction in any medium, provided the original work is properly cited. (C2020 by author.

\section{Introduction}

Independence is one aspect that must be owned by every individual, including children with special needs. The number of children with special needs from year to year is increasing. Based on 2009 Central Statistics data from Indonesia's population there are 2.8 million people with disabilities and around 600 thousand of them are children (21.42\%) of school age (aged 5-18 years) and the mental retardation population of school age children in Indonesia an estimated half of the total number of people with disabilities or around 1.5 million people, and only 54,000 children can attend formal education in special schools.

The number of persons with disabilities in Indonesia $21.42 \%$ are school age children. The population of mentally retarded children in Central Java Province ranks second after East Java at 52,800 people. According to the Central Education Development Special Education Office of Central Java Province, the number of SLB students in Central Java is 15,480 children (Kemendikbud, 2010). It can be concluded that the number of people with disabilities at school age in Indonesia that the population of mentally retarded children in East Java Province ranks first with a total of 52,800 people.

WHO estimates that the number of children with disabilities is around $7-10 \%$ of the total child population. Based on survey research conducted in developing countries by UNICEF and the University of Wisconsin in 2008, showed the results of monitoring health conditions in women and children as much 
as $52.4 \%$ of children aged 6-9 years who are in school and experience disability unable to do activities daily independently. According to the Central Statistics Agency in 2012 as many as $2.8 \%$ had difficulty taking care of themselves. In Central Java alone there are 88,345 people who have difficulty taking care of themselves. The number of children who have difficulty taking care of themselves or cleaning the whole body is around 2,044 people (Ministry of Health, 2014). This data shows that most children with disabilities are unable to perform daily activities independently and have difficulty taking care of themselves.

Children with special needs need to be known and identified from the group of children in general. There are several terms used to indicate the condition of children with special needs (ABK). According to Cahya (2013) children with special needs are children who experience deviations, disabilities, or disabilities in physical, mental, emotional and social aspects or from a combination. This condition makes $A B K$ requires special education services that are in accordance with their irregularities, disabilities or disabilities. The term children with special needs is the latest term used, and is a translation of children with special needs. In addition, there is a new term that is developing widely and developing, namely diffable, actually short for diference ability.

Cahya (2013) states that children who are categorized as children with special needs are children who experience mental retardation, learning disabilities or attention disorders, emotional or behavioral disorders, physical barriers, communication, autism, traumatic brain injury, hearing impairment, barriers vision, and children who have special talents. Children with special needs in Indonesia are estimated to be between $3-7 \%$ or around 5.5-10.5 million children under the age of 18 have disabilities or are categorized as children with special needs.

RISKESDAS (2017) states that around 4 percent of children aged 15 to 19 years experience significant difficulties in at least one functional domain (vision, hearing, walking, concentrating and understanding others as well as self-care) and are therefore considered to be individuals living with disability. According to the 2010 Census it was found that about 2 percent of children aged 0 to 14 years have a disability. Two percent of all children aged 0 to 18 in Indonesia number around 1.5 million children. Four percent of all children will increase the total number of about 3 million children and adolescents living with disabilities.

According to the Data Collection of the Directorate of Social Rehabilitation of Persons with Disabilities (2009), the number of children with disabilities is increasing from year to year. Based on data from the Social Service the number of people with disabilities in 2011 was 29,110, consisting of 15,667 men and 13,443 women. Whereas for 2010 the number of people with disabilities was 36,607, which consisted of 19,867 men and 16,990 women. In 24 provinces there were 65,727 children, consisting of 78,412 children with mild disability, 74,603 children with moderate disability, and 46,148 children with severe disability. Then according to the National Socio-Economic Survey on March 1, 2011 the number of Indonesian children was $82,980,000$, of that population $9,957,600$ children were children with special needs in the category of persons with disabilities.

Children with disabilities are also entitled to receive proper education, in the context of education, education is the right of all citizens without distinguishing the origin, socioeconomic status, or physical condition of a person including children who have disabilities as mandated in the 1945 Constitution Article 31 Paragraph 1 which states that every citizen has the right to receive teaching. Also in Law Number 4 of 1997 Article 5 states that every person with disabilities or special needs has rights in aspects of life and livelihood. Education plays a very important role in the life of a country to ensure the survival of the nation and state.

Children with special needs are also entitled to the same educational services. However, children who have special needs cannot be compared to others, because these children have special needs and must get special services too. Therefore inclusive education is a system of providing education for children who have certain limitations and other children who are united without considering their respective limitations. According to the Directorate of SLB Development (2010) inclusive education is an education service system that provides opportunities for all children to learn together in public schools by paying attention to diversity and individual needs, so that the child's potential can develop optimally. The spirit of inclusive education is to provide the widest possible access to all children, including children with special needs to obtain quality education and educational services that are appropriate to their needs. 
Cahya (2013) states that the characteristics and constraints of children with special needs require special forms of educational services that are tailored to their abilities and potential. Through the segregation education service system, the administration of education is carried out specifically and separately from the administration of education for normal children. SLB is a formal educational institution that organizes teaching and learning activities for students with disabilities.

Formal education is largely determined by the implementation of learning activities, both in the classroom and at home. Efforts to improve the quality of teaching and learning of students require ways of learning or learning habits early on, both in the school environment and at home. It aims to provide adequate planning so that it can affect student learning activities. Efforts to achieve achievement and develop abilities optimally, children with special needs usually attend the Segregative School (SLB).

Students who develop with independence and responsibility normally will have a positive tendency in the future. In addition, students will tend to excel and have confidence (Novita, 2007). According to Fatimah (2010) independence in children begins in the family and is influenced by parenting patterns in the family. Parents who play a role in caring for, guiding, and helping children to become independent. If parents can provide a good pattern of care for children, the child will be independent in carrying out daily activities including personal hygiene independence.

Personal hygiene is self-care to maintain health both physically and psychologically (Ambarwati et al, 2009). Personal hygiene is one of the basic human needs which consists of skin care, hair care, oral care, nail care, and care of the genetal. The purpose of personal hygiene is to maintain personal hygiene and improve one's health status and as a form of prevention against an illness.

Good personal hygiene must begin to be applied early on in children, starting when the child enters the golden age. If early on, personal knowledge about personal hygiene has been given, so children's knowledge about personal hygiene will be more mature and can foster a habit of doing personal hygiene practices. The form of independence of personal hygiene in preschoolers is that children can brush their own teeth even though it is not perfect, take their own baths with instructions, urinate in the toilet, and wash their hands without assistance. Most preschoolers are able to do toilet training independently in the preschool period although some children may still be assisted by parents (Potter and Perry, 2009).

Parents are the first educators for children. Parents are a component of the family consisting of fathers and mothers (Mansur, 2005). Parents have the responsibility for certain stages that take children to be ready in community life, so it is important to involve the role of parents in helping children to be able to learn well, be able to communicate and interact well, be able to create good relationships with children, pay attention to children, as well as giving a great influence on children's learning success. Parents should increase knowledge and find out more about the patterns of care that have been given to children.

Parenting can form personality patterns in children. According to Wibowo (2012), parenting is defined as a pattern of interaction between children and parents which includes meeting physical needs (such as eating and drinking) and non-physical needs, such as attention, empathy, and affection. The characteristics of children are to imitate what they see, hear, feel, and experience. Therefore, the character of children will be formed in accordance with parenting by their parents. As stated Wibowo (2012) parenting parents who receive, will make children loved, protected, considered valuable, and given support by their parents. Based on the understanding of parenting above, it can be said that parenting is a behavior to nurture, educate, and practice the habits of children to carry out daily activities as an expression of a sense of responsibility to children and is relatively consistent.

Parenting is influenced by several factors. Adawiyah (2017) stated in his research that the level of education owned by parents had a direct relationship with parenting practices applied by the family, where the higher the education of parents, the better parenting applied. And vice versa the lower the education owned by parents, the adoption pattern will be less good.

Arief's opinion is in line with the explanation of Suririnah (2010) which states that the mother's work is one that determines parenting. Parents who have jobs from the working class more value adjustments to external standards, while parents from the middle class place more emphasis on adjustments to standards of behavior that have been internalized. While the number of children owned by the family will affect the parenting that is applied by parents. The greater the number of children in the family, the tendency is that parents are not so attentive and time is shared with other children. 
The effects of parenting are very diverse. Mantali, Umboh, and Bataha (2018) states that children are given democratic parenting by their parents, but are still not independent. Factors that cause children to become independent at the age of 5-6 years are internal factors within the child such as emotional and intellectual children, and external factors namely the environment around children such as peers. Peers can be the main factor that makes children who have been given a democratic upbringing but cannot be independent because peers often help children do things that should be done by their own children without help, but are often helped to make children's self-confidence less and children feel always need others when doing something.

Hidayati (2014) states that there is a negative relationship between parents' authoritarian parenting and children's independence. This means that the higher the application of parents' authoritarian parenting, the lower the level of children's independence. The application of authoritarian parenting is characterized by hard and rigid parenting. Parents tend not to respect the opinions of children. Children are not given enough space to express themselves by strictly controlling and restricting children's activities. Dewi (2017) states that parents who have more authoritarian parenting do not give freedom to children in accordance with their wishes. In addition, parents rarely give gifts or praise for the achievements that have been obtained by children. Parents also often limit the child in doing whatever he wants. Parents also rarely feel satisfied with what the child has done. This is because in children with mental retardation, parents are more likely to apply rules or prohibitions because children who are mentally retarded need more supervision than other normal children, so parents limit the activities carried out by children.

Pratiwi and Mualimah (2018) states that good parenting in pre-school age children is needed to shape the child's independence in personal hygiene. so that good parenting in pre-school age children is needed to establish the independence of children in brushing their teeth early on. Independence that has been implanted in children can prevent dental disease that can attack children. The parenting method used in this study is democratic parenting. Children are given the freedom to make the desired choice without coercion from parents. Parents will only guide and tell children to brush their teeth, if the child does not brush their teeth when it is time to brush their teeth. Lestari and Sopingi (2018) states that authoritarian parenting and the independence of autistic children tend to be very low, permissive parenting patterns of parents and autistic children tend to be moderate, and democratic parenting tends to be high. Parenting patterns with three types of parenting can affect the independence of children with autism. A good parenting style will create high independence so that parenting can be interpreted as able to create a harmonious, harmonious and balanced relationship when applied wisely and well in order to increase the independence of children with autism.

Based on preliminary observations made on November 13, 2018 in SLB / G-AB Helen Keller Indonesia obtained information through interviews from the assistant teacher in the class who revealed that the role of parents of students were supportive and some were not supportive, such as never met a teacher to ask how the child's development. One of the obstacles experienced by the accompanying teacher in the class is when parents do not re-train what the teacher has taught students to apply at home so that it inhibits student independence even though the teacher has taught how to learn independently. Students who experience intellectual disabilities will have difficulty in taking care of themselves such as bathing and brushing their teeth, so that they need help from others.

Factors that influence parents do not train the child's personal hygiene independence when at home, among others, parents are busy taking care of other children, are busy at work, and some are always pampering so that it inhibits children's independence. Parenting patterns will form the independence of children, one of which is in terms of education or the development of personal hygiene independence behavior in children. Parenting provided by parents includes educating and caring for their children. Parenting must be adapted to the needs of children. Parents who apply good parenting will certainly inform the child about the importance of personal hygiene and teach children to do personal hygiene activities independently. Children who are able to do personal hygiene independence activities include washing hands, combing hair, toilet training, bathing and brushing their teeth. Children will do step by step without being accompanied by others while children who have not been able to do personal hygiene independence activities need to be physically assisted by others.

\section{Method}

The influence of parenting parents on the personal ... | 110 Indonesian Counselor Association (IKI) | DOI: 10.23916/0020200526030 
This research approach includes quantitative research, because the symptoms of observations are manifested in the form of numbers and then analyzed with statistical analysis techniques. This type of research is a correlational descriptive study. This study aims to determine the effect of parenting parents on the personal hygiene independence of children with special needs in SLB G / AB Helen Keller Indonesia.

The population of this study is parents and students at SLB G / AB Helen Keller Indonesia. Sampling in this study uses a saturated sample, which uses all members of the population as a sample. This is done because the number of population to be studied is small or less than 30 . Therefore the sample in this study are parents and students in grades 1, 2, 3, 4, 5 and 6.

The data collection of this study uses a scale of parenting and personal hygiene independence questionnaire. The parenting scale was developed from Gordon (in Syamaun, 2012). While the personal hygiene questionnaire was developed from Poter and Perry (2009). The results of the validity test of the parenting scale instrument and the personal hygiene independence questionnaire through the calculation of the product moment formula, showed the magnitude of the $r$ count of all questions the value was greater than the $r$ table of 0.396 . Thus it can be concluded that all items of parenting scale parenting instruments and personal hygiene independence questionnaire were declared valid. The reliability test results of the Cronbach Alpha coefficient values throughout the study variables were greater than 0.6, namely the parenting scale of 0.965 and the personal hygiene independence questionnaire of 0.939 . Thus, all the questions in the parenting scale instrument and the personal hygiene questionnaire are reliable or reliable.The data analysis technique used in this study is regression analysis technique.

\section{Results and Discussions}

The results of data analysis through multiple linear regression can be described in table 1.

Table 1. Multiple Linier Regression Test Results

\begin{tabular}{llccccc}
\hline Variable & & B & beta & t count & Sig t & Description \\
\hline & $\begin{array}{l}\text { (Constant) } \\
\text { Authoritarian } \\
\text { parenting }\end{array}$ & 0.697 & 0.390 & 3.262 & 0.004 & Significant \\
$\begin{array}{l}\text { Democratic } \\
\text { parenting }\end{array}$ & 0.670 & 0.348 & 2.352 & 0.029 & Significant \\
\hline $\begin{array}{l}\text { Permissive } \\
\text { parenting }\end{array}$ & 0.439 & 0.354 & 2.297 & 0.032 & Significant \\
\hline F count & 20,391 & & & & \\
\hline Sig F & 0.000 & & & & \\
\hline R square & 0,708 & & & \\
\hline Variabel Dependent & & & & \\
\hline
\end{tabular}

Based on data analysis using multiple linear regression tests, it is known that the most dominant influence on personal hygiene independence is authoritarian parenting, where the significance value of authoritarian parenting is 0.004; democratic parenting practice of 0.029; and permissive parenting of 0.032 . Based on multiple linear regression analysis shows the magnitude of the coefficient of determination ( $\mathrm{r} 2$ square $)=0.708$, meaning that the independent variables jointly affect the dependent variable by $70.8 \%$ and the remaining $29.2 \%$ means that it is influenced by other variables not included in the research model.

Authoritarian parents tend to have high control in using their power. They rely more on punishment and are unresponsive. They value obedience and do not tolerate their children. Authoritarian parents tend not to give freedom to their children to express opinions about decisions and regulations made by parents and force children to obey these rules without giving an explanation (Maccoby and Martin, in Terry, 2004). Authoritarian parenting is a method used by parents in educating children and caring for children by using strict controls and making rules and restrictions that can and should not be done by children, and provide penalties if the child is guilty.

Authoritarian parenting is a way used by parents in educating children and caring for children by using strict controls and making rules and restrictions that can and should not be done by children, and 
provide punishment if the child is guilty. Authoritarian parenting is revealed by using an authoritarian parenting scale consisting of aspects of behavioral guidelines, the quality of emotional relationships, supportive behavior and the level of conflict. The higher the score for parenting, the higher the authoritarian parenting, the lower the score, the lower the authoritarian parenting. Independence is the child's ability to achieve something he wants after the child explores his surroundings. This encourages children to not be dependent on parents emotionally and transfer it to peers, able to make decisions, responsible and not easily influenced by others.

This study also shows that there is an influence of parenting democratically on the personal hygiene independence of children with special needs in SLB / G-AB Helen Keller Indonesia. Democratic care encourages children to be independent but still sets limits and controls over their verbal deliberative actions and parents show warmth and affection for the child. Democratic parenting is parenting that involves and fully accepts children. This type of parent encourages their children to learn independently, but parents still set limits and supervision of the child. Baumerind (in Santrock, 2002) argues that democratic parenting encourages children to make children independent of personal hygiene but still sets limits and controls over the actions of the child and parents show their warmth and affection. This situation allows children to learn responsibly. Democratic parents also see children as individuals who are growing and developing and have their own initiatives. This situation allows the independence of learning to foster children's confidence.

In line with the above research, Hasan (2012) mentions democratic parenting that parents provide freedom accompanied by a sense of responsibility to children to move and mingle with friends, acceptance attitude of parents who are responsive and very attentive to the needs of their children accompanied by reasonable restrictions so children are given the power to convey the problem. Communication occurs in two directions, communication runs very smoothly, namely the discussion of children and parents.

This study also shows that there is an effect of permissive parenting on the Personal Hygiene Independence of children with special needs in SLB / G-AB Helen Keller Indonesia. Permissive parenting is a style in which parents are very much not involved in children's lives. Children who have parents who ignore their children feel that there is another aspect to their lives than they do. These children tend not to have independent abilities. They often have low self-esteem, are immature and may be alienated from family. In adolescence, they may display truant and naughty attitudes. Permissive parenting is a style in which parents are very uninvolved in the lives of children where parents are very involved in the lives of their children but establish little limits or control over them.

Permissive parenting can be interpreted as a pattern of parental behavior in interacting with children, which frees children to do what they want to do without questioning. This parenting does not use strict rules and even less guidance is given, so there is no control or control and demands to children. Freedom is given full and children are allowed to make decisions for themselves, without consideration of parents and behave according to what they want without any control from parents.

The results of the above research are in line with Winarsih (2010) which states that one of the factors that influence children's independence is parenting. Parents are the closest environment to children, people become an example or figure for children. This study shows that there is an influence of parenting in an authoritarian, democratic and permissive manner to the personal hygiene independence of children with special needs in SLB / G-AB Helen Keller Indonesia. Authoritarian parenting has the highest influence on the personal hygiene independence of children with special needs in SLB / G-AB Helen Keller Indonesia. Authoritarian parenting applied by parents can help the personal hygiene independence of children with special needs later through parental authoritarian parenting in the early stages of growth to train personal hygiene independence so that children do not depend on others and the child will get used to being independent in doing any activities. The efforts made by parents in developing the personal hygiene independence of children with special needs are expected so that children can develop properly in the aspect of independence.

This independence is also one of the goals of guidance and counseling services. Guidance and counseling teachers must play an active role in implementing counseling guidance services, especially in developing the personal hygiene independence of children with special needs. Children with special needs have limitations that require the role of parents and teachers in achieving independence. The purpose of guidance and counseling for children with special needs is to help children with special needs in getting to 
know their talents, interests and abilities and to develop their potential optimally according to their abilities.

Guidance and counseling for children with special needs is a process of assistance to children with special needs carried out with the aim of helping children problems both personal, social, learning and career. Guidance and counseling for children with special needs is carried out carefully and carefully because it involves the physical and mental limitations of the child or counselee. To carry out guidance and counseling, a counselor must uphold the principle that individuals are unique and different. Through information services aim to equip individuals with a variety of knowledge and understanding of various things that are useful for knowing themselves, planning and developing patterns of life as students, family members and the community. Understanding obtained through information is used as a reference in increasing personal hygiene in carrying out daily life.

Information services are provided to children with special needs in order to have provisions for their lives in the future according to the abilities and conditions of children with special needs. Providing information about the independence of personal hygiene is considered beneficial for children with special needs through direct communication and is emphasized by using media that can help facilitate the learning of children with special needs.

Guidance and counseling services for children with special needs require counselors to have creativity and innovation so that the service delivery process runs smoothly according to the limitations of the child or counselee. Guidance and counseling services can be implemented well if based on good planning, a counselor must have the competence and skills to carry out guidance and counseling without having competence and skills, guidance and counseling services must be carried out continuously with each other so that the implementation of services can run optimally according to what was expected.

\section{Conclusions}

Parental parenting in an authoritarian, democratic, and permissive manner partially has a significant and positive influence on the Personal Hygiene Independence of children with special needs in SLB / G-AB Helen Keller Indonesia. Authoritarian parenting has the most significant and positive influence on the personal hygiene independence of children with special needs in SLB / G-AB Helen Keller Indonesia. Parents play an important role in the independence of personal hygiene of children with special needs in order to be able to shape the child into an independent person. The results of this study indicate that parenting in an authoritarian, democratic and permissive manner simultaneously has a significant and positive influence on the personal hygiene independence of children with special needs in SLB / G-AB Helen Keller Indonesia.

Based on the conclusions and discussion of the results of the study, the suggestion put forward in this study is that as a second parent at school, teachers are expected to provide examples of personal hygiene independence to students so that they can carry out personal hygiene independence wherever they are. For parents, the results of this study can be seen that the most authoritarian parenting influence on the independence of personal hygiene. At an early age parents who apply excessive authoritarian parenting will affect the independence of children, therefore parents who apply authoritarian parenting to their children should be combined with other parenting patterns such as democratic parenting.

\section{References}

Adawiyah, R. (2017). Pola Asuh Orang Tua dan Implikasinya Terhadap Pendidikan Anak. Jurnal Pendidikan Kewarganegaraan, 7(1), 33-48.

Cahya, L.S. (2013). Adakah ABK di kelasku? Bagaimana guru mengenali anak berkebutuhan khusus. Yogyakarta: Familia.

Fatimah, E. (2010). Psikologi Perkembangan (Perkembangan Peserta Didik). Bandung: Pustaka Setia.

Hasan, M. (2012). Pendidikan Anak Usia Dini. Yogyakarta: Diva Press.

Hidayati, N. I. (2014). Pola Asuh Otoriter Orang Tua , Kecerdasan Emosi ,. Jurnal Psikologi Indonesia, $3(01)$. 
Lestari, D. D. (2018). Hubungan pola asuh orangtua dan kemandirian anak autis. Jurnal Ortopedagogia, 4(1), 39-42. https://doi.org/10.17977/jo.v4i1.4404

Mansur. (2005). Pendidikan Anak Usia Dini dalam Islam. Yogyakarta: Pustaka Pelajar.

Mustika Diana Pratiwi, M. M. (2018). Hubungan Antara Pola Asuh Orang Tua Dengan Tingkat Kemandirian Personal Hygiene Dalam Mencuci Tangan Dan Gosok Gigi Pada Anak Pra Sekolah. Darul Azhar, 6(1), 39-47. https://doi.org/10.1017/CBO9781107415324.004

Novita. (2007). Melatih Kemandirian Anak. Jakarta. TIM.

Potter, P.A., and Perry, A.G. (2009). Fundamentals of Nursing: Concepts, Process, and Practice. (7th ed). St. Louis: Mosby.

Prasekolah, U., Tk, D. I., Pembina, N., \& Bataha, Y. B. (2018). e-journal Keperawatan (e-Kp) Volume 6 Nomor 1, Februari 2018 Hubungan Pola Asuh Orang Tua Degan Kemandirian Anak Usia Prasekolah di TK Negeri Pembina Manado. 6, 1-8.

Santrock, J.W. (2002). Life Span Development (Perkembangan Masa Hidup). Jilid 2, Penerjemah: Chusairi dan Damanik. Jakarta: Erlangga.

Suririnah. (2010). Buku Pintar Kehamilan dan Persalinan. Jakarta: PT. Gramedia Pustaka Utama.

Syamaun, N. (2012). Dampak Pola Asuh Orangtua dan Guru terhadap Kecenderungan Perilaku Agresif Siswa. Yogyakarta: Ar-Ruzz Media.

Terry, D. J. (2004). Investigating the Relationship between Parenting Styles and Delinquent Behavior Investigating the Relationship between Parenting Styles. Parenting, 15(1), 1484-1487. https://doi.org/10.1016/j.sbspro.2011.03.315

Vonny Khresna Dewi. (2017). Hubungan Pola Asuh Orang Tua Dengan Tingkat Kemandirian Anak Retardasi Mental Ringan. An-Nadaa, 21-25.

Wibowo, A. (2012). Pendidikan Karakter Anak Usia Dini. Yogyakarta: Pustaka Pelajar.

Winarsih. (2010). Hubungan Pola Asuh Terhadap Kemandirian Belajar Anak di RA/BA Kecamatan Grogol Kabupaten Sukoharjo Tahun Ajaran 2010 / 2011. Skripsi Thesis, Universitas Muhammadiyah Surakarta. 